\title{
Indonesia's Democracy in the 21st Century: A Book Review
}

\author{
Farahdiba Rahma Bachtiar \\ Royal Melbourne Institute of Technology (RMIT)
}

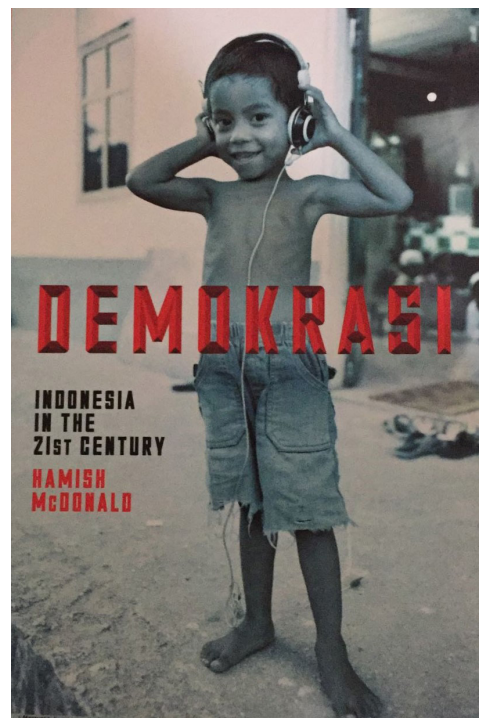

$\begin{array}{ll}\text { Title } & \text { : Demokrasi: Indonesia in the } \\ & \text { 21st Century } \\ \text { Author } & : \text { Hamish McDonald } \\ \text { Year } & : 2014 \\ \text { Publisher } & : \text { St. Martin's Press } \\ \text { Page } & : 320 \text { pp } \\ \text { Price } & : \text { AUD } 36.49 \\ \text { ISBN } & : 9-781922-231437 \\ \text { Format } & : \text { Paperback }\end{array}$

There are plenty of books wrote about Indonesia's democracy by foreign scholars. Yet, many of them are very heavy read when it comes to politics. The book is an alternative. Intentionally wrote to offer brief overview about Indonesia's, the book by McDonald indeed is presented to be ease for understanding yet contains fruitful topics on Indonesia's democracy. His long experience as a journalist and writer of the classic book -Suharto's Indonesia, as well as his journey to the country gave him adequate capacity to understand Indonesia better in the past and today. And thus it is why as mentioned before that he offers what he called "authoritative introduction", because he is not a pure academia. Therefore, it is better not to expect depth analysis about any particular subject. But the novelty of the book lies on its details of some particular cases which not too often revealed by other books.

Further, there are fourteen chapters of the book in which each of them highlight critical theme about Indonesia. From the first chapter of Nusantara to the last - Indonesia in the World, McDonald tries to unveil what changes and what remains about Indonesia. He certainly does great work on putting the social and political context of the country to portray the history of the young nation. McDonald brings to light the notion of democracy as an integral part of modern Indonesia. Many thought that the topic of democracy is popular and devoted to Indonesia after Suharto's fall. However, it is in fact has been a crucial part of Indonesia's politics, culture and people for centuries. 
The first chapter -Nusantara begins McDonald's narrative about the Indonesia's classic democracy. He finds that since hundred years ago, the idea of Indonesia with its diversity has lived in Indonesians society in the days of Sriwijaya and Majapahit kingdoms. But not until the European explorer arrived, took control over trade and soon manipulated people in Batavia, Java, Aceh, Ambon and other parts of the archipelago, the locals were fought in their own. In accordance to that, McDonald provocatively said that even if the Dutch did not use politics of Divide et Impera to rule,the nation would be still colonialized by them. Simply put, there was inherently weakness of Indonesia even before the Dutch ruled. But taking it in a positive way, there is a truth behind that statement. Indonesia's democracy is inevitably fragile. It is important to bear in mind, that the country consists of hundreds of ethnicities and they live across the archipelago. Naturally, they shares similarities as much as differences. Fortunately, although it was too late for the Dutch to give Indonesians 'debt of honours' during three centuries of colonialism, they finally provided education to upper class children. From those local intellectuals thus, the idea of Indonesia came into being as a nation state in 1920. Later, he described that the early Indonesia was full of Soekarno's effort to strengthen the nation building. But the content of the first chapter, as many foreigner experts might do, to some extent is bias. McDonald is clearly cautious in revealing the domination done by the colonials. I would say that it will possibly helpful to show the grounds behind some Indonesian's negative perception towards democracy from the west.

In the next two chapters McDonald then explained about Indonesia after independence and the socio political problem followed. In the second chapter, the Lubang Buaya (Crocodile Hole) is used to mark the end of Sukarno's presidency. Most of this chapter discusses about the challenge of defending democracy and PKI (the Indonesian communist party). The Sukarno's slogan of NASAKOM (nasionalisme-agama dan komunisme or nationalism-religion and communism) brought back the kingly rule of an old Indonesia. As this viewed to be the failure of democracy to survive, McDonald argues that after all the best question to think is not 'Why democracy failed in Indonesia' but instead 'Why should it have survived?' That appealing question is highly relevant to ask in the third chapter. During Soeharto's Era, Indonesia was once again struggle for democracy. Learned from Indonesia in the past, Soeharto avoided giving the power to civilians and his ultimate target was to prevent an economic collapse. The help from the US for the anti-communist movement and the modernisation as the economic experts' success, brought the thirty years of Suharto's in power and the continuity of controlled electoral election. Like many people found the regime as a manifestation on Javanese kingship, McDonald also thought same thing. But to McDonald himself, the New Order was in fact the legacy of the Dutch. He points out that there some resemblances between the New Order System and the Dutch administration in terms of a powerful governor general, weak people's council, the villagers as a passive mass and extractive-based 
economy. Though the Dutch disease is relevant to Indonesia's case, his point of view on this is appealing, especially because in the literature the political system of New Order was much related to its neighbours (as an authoritarian regime) and bureaucratically pattern (as other Asian Model).

Following the sequence of Indonesia's political system, the fifth until the last chapter explain about Indonesia after the Reformasi (Reformation), including the local chaos and separatism, religious movement the change within military, the law enforcement, and its outward foreign policy. It was not surprising, after a long period of oppressive government, the issue of new democracy came into place. There had been fundamental transformation in Indonesia's system including decentralisation law and election in all level of political structure. At first, there was hope, but this dramatic transformation made the country lost its path for quite a decade. All of presidents after Suharto have failed to embrace the democratic meaning. McDonald called the Habibie's presidency as tumultuous and Gusdur's as wild. For Megawati, he identifies her presidency as inert and complacent. Not until SBY was in the office, (at first) most of the mess left has assumed to be diminish and Indonesia has moved on from the agonizing past.

It was probably the tsunami, the new phase democracy then found its way. As many separatism movement arose. The case of the strongest rebellious movement in Aceh- Gerakan Aceh Merdeka (GAM, Free Aceh Movement), finally came to end after the 2004 Tsunami. Meanwhile the new figures from South Sulawesi-Jusuf Kalla gained his momentum as the leader on the peace negotiation. GAM had little chance to fight and the foreign pressure to both sides was very strong to start peace negotiation. This was also the ticket given by western countries to the new president-Suusilo Bambang Yudhoyono to lead in two terms. In contrary to Wiranto's willingness to diminish Dwi Fungsi (Dwi Fungsi Doctrine) of the military, SBY who known as reformist inside the army found his way to be a part of the cabinet. Prior to this, many political positions and business held by military personnel. Again, McDonald challenges this by adding Agus Widjojo's statement (SBY old classmates), "I don't see them (military personnel) in the society. I don't see them being employed in counter-terrorism, or anything..." For this reason, the presence of SBY perhaps motivated military to step forward. Consistent with that the success of SBY might be caused by his similar characteristics with Suharto; Javanese, moslem, came from the army and had formal higher education. It sounds odd that Indonesia's after Suharto hoped to have another person with military background. But the long phase of unsuccessful transition done by civilian leaders might give rise to Indonesian's trust over SBY.

SBY's presidency got his timing. The rise of China and India has an effect to Indonesia's economy due to the commodity boom. Indonesia changed from poor nation to middle income country. SBY came with social welfare programs balancing the state's wealth for helping the poor from Raskin to health insurance scheme. But 
McDonald again tends to think- this was too ambitious. In the meantime, while the economic was growing and even leaving some developing countries behind, SBY's ten years of presidency had to face rise and fall of democracy during his time and any possible industrialisation problems like inequality and environmental issues. From the case of Organisasi Papua Merdeka (OPM, Free Papua Movement) to greenhouse emission and palm oil, SBY indeed has seen all industrializing country's problem. But the most horrifying thing was the issue on religion. The religion agenda started to raise, the politics and campaign intensively related to Islamic value. Politicians also took this for their own sake and played an Islamic card to gain votes and sympathy. This has been happening since Reformation but continuingly serious after SBY was in office. There was also a big fight between the police and Corruption Eradication Commission. The corruption case remained a critical problem even after Reformation, especially because the new era of direct election has been costed much. Yet, after all, McDonald concluded that Indonesia after SBY especially after his second term pictured a disappointment. Perhaps, that was most of Indonesians also perceived. But let us not forget about how Indonesia has transformed during SBY administration and even if he failed, Indonesians themselves chosen him.

Generally speaking, McDonald's work is lack in elaborating the story of Indonesia's democracy to the facts and information he provides. Despite the clues and some captivating questions in McDonald's book, however he creates a space for readers to assume the link between particular events to the topic of democracy. Not until reaching the last few chapters, the book seems making sense to the readers. For scholars in this social and political science, the connection is absolutely obvious. But for those with different background, as an introduction to Indonesia's democracy, it might look like a standard historical book. 